\title{
Nálezy kultury s lineární keramikou ze starých fondů Moravského zemského muzea z obce Bohutice
}

\section{The findings of Linear Pottery Culture from old collections of Moravian Museum from Bohutice}

\section{Zdeněk Hájek / Alena Humpolová / Alžběta Čerevková}

\begin{abstract}
Abstrakt
Předkládaná studie se zabývá vyhodnocením archeologických nálezů z katastrálního území obce Bohutice, které ve sbírkách Moravského zemského muzea v Brně nesou označení "kultura s lineární keramikou". Většina materiálu byla získána během povrchových sběrů v zázemí obce. Hlavním cílem studie je provést rozbor jednotlivých komponent kolekce a verifikovat jejich souvislost s osídlením dané kultury.
\end{abstract}

\section{Klíčová slova}

Neolit, kultura s lineární keramikou, sídliště, keramika

\begin{abstract}
The paper presented is dealing with analysis and evaluation of archaeological finds from the cadastral district of Bohutice village, which in the collections of the Moravian Museum bear the label "Linear Pottery Culture". The most part of the finds were acquired during surface collecting in the outskirts of the village. The main goal of the study is to carry out the analysis of individual components of the collection and verify their relation to settlement of the culture in question.
\end{abstract}

\section{Keywords}

Neolithic, Linear Pottery Culture, settlement, pottery

Předložená práce vznikla za finanční podpory Ministerstva kultury v rámci institucionálního financování na dlouhodobý koncepční rozvoj výzkumné organizace Moravské zemské muzeum (DKRVO MK 000094862). 


\section{1. Úvod}

Nálezy z katastrálního území obce Bohutice ve sbírkách Moravského zemského muzea představují nevelkou kolekci keramiky a štípané a broušené kamenné industrie. Většina materiálu byla podle dostupných průvodních informací získána během povrchových průzkumů v 60. letech minulého století v intravilánu obce. U některých nálezů však nelze jejich původ dohledat. To se týká především kamenné industrie. Již během povrchových průzkumů byla zřejmě provedena určitá selekce materiálu (např. mazanice, drobných zlomků keramiky apod.), čímž byly ztraceny některé důležité informace o charakteru zdejšího osídlení. Na základě dochovaných artefaktů je nicméně možné lokalitu alespoň relativně datovat a přiblížit tak její pozici v rámci širšího kontextu osídlení kultury s lineární keramikou (dále jen LnK) na Moravskokrumlovsku.

\subsection{Poloha a přírodní prostředí}

Obec Bohutice se nachází v západní části Jihomoravského kraje a náleží do okresu Znojmo; nachází se 6 km jihovýchodním směrem od Moravského Krumlova.

Nejbližšími přirozenými vodními zdroji jsou potoky Olbramovický (asi 1,5 km východním směrem) a Našiměřický (asi 2,5km jižním směrem). Nejbližším větším vodním tokem je řeka Rokytná tekoucí ve vzdálenosti asi $5,5 \mathrm{~km}$ severozápadně obce. Bohutice se rozkládají na jihozápadním svahu zvlněného terénu Jevišovické pahorkatiny, dále na východ a jihovýchod směrem k Olbramovicím a Branišovicím je krajina více rovná a otevřená.

Z geomorfologického hlediska spadá daná oblast na pomezí celků Bohutického lesa a Drnholecké pahorkatiny. Bohutický les přitom náleží Brněnské vrchovině, kdežto Drnholecká pahorkatina je již součástí Západních Vněkarpatských sníženin. Jedná se tedy o rozhraní dvou rozdílných geomorfologických podsoustav. Bohutický les představuje jižní část Leskounské vrchoviny, jedná se o hřbet protažený ve směru SV-JZ a sklánějící se od $\mathrm{SV}$ k JZ, na SZ je výrazně omezen zlomovým svahem, na JV plynule přechází do Dyjsko-svrateckého úvalu. Severovýchodní část je složena z žul a granodioritu, jihozápadní část tvoří krystalinikum a permokarbonské usazeniny, objevují se zde také ostrůvky neogenních usazenin (Demek ed. 1987, 115). Severní část Leskounské vrchoviny představuje Krumlovský les. Tvořený je hlavně žulami a granitoidy brněnského plutonu, ostrůvky devonského vápence a zbytky miocenních usazenin. Ve střední části se nacházejí balvany jurských rohovců. Nacházejí se zde četné útvary vzniklé tropickou a kryogenní erozí a odnosy žuly: izolované skály, balvany, skalní mísy, škrapy apod. Krajina je převážně zalesněná (Demek ed. 1987, 302; Bína - Demek 2012, 102-103). Krumlovský les představuje významný zdroj rohovců v průběhu celého pravěku (Oliva 2010). Drnholecká pahorkatina je spíše nížinná plochá pahorkatina, jejíž podloží tvoří neogenní sedimenty (štěrky, písky, vápnité jíly) a kvartérní spraše. Krajinu zde modeluje tok řeky Jevišovky a toky menších vodotečí (Demek ed. 1987, 171; Bina - Demek 2012, 259).

\section{Historie osídlení Bohutic}

Doklady paleolitického osídlení v okolí Bohutic prozatím chybí, osídlení zde evidujeme od staršího neolitu. Již I. L. Červinka zde zaznamenal náhodné nálezy kamenné broušené industrie, bohužel bez bližšího místního či časového určení. Pozůstatky lineární osady byly nicméně zjištěny v roce $1926 \mathrm{v}$ areálu sokolského cvičišstě, který leží v samotném centru obce. V těchto místech se měl údajně nacházet též hrob dané 


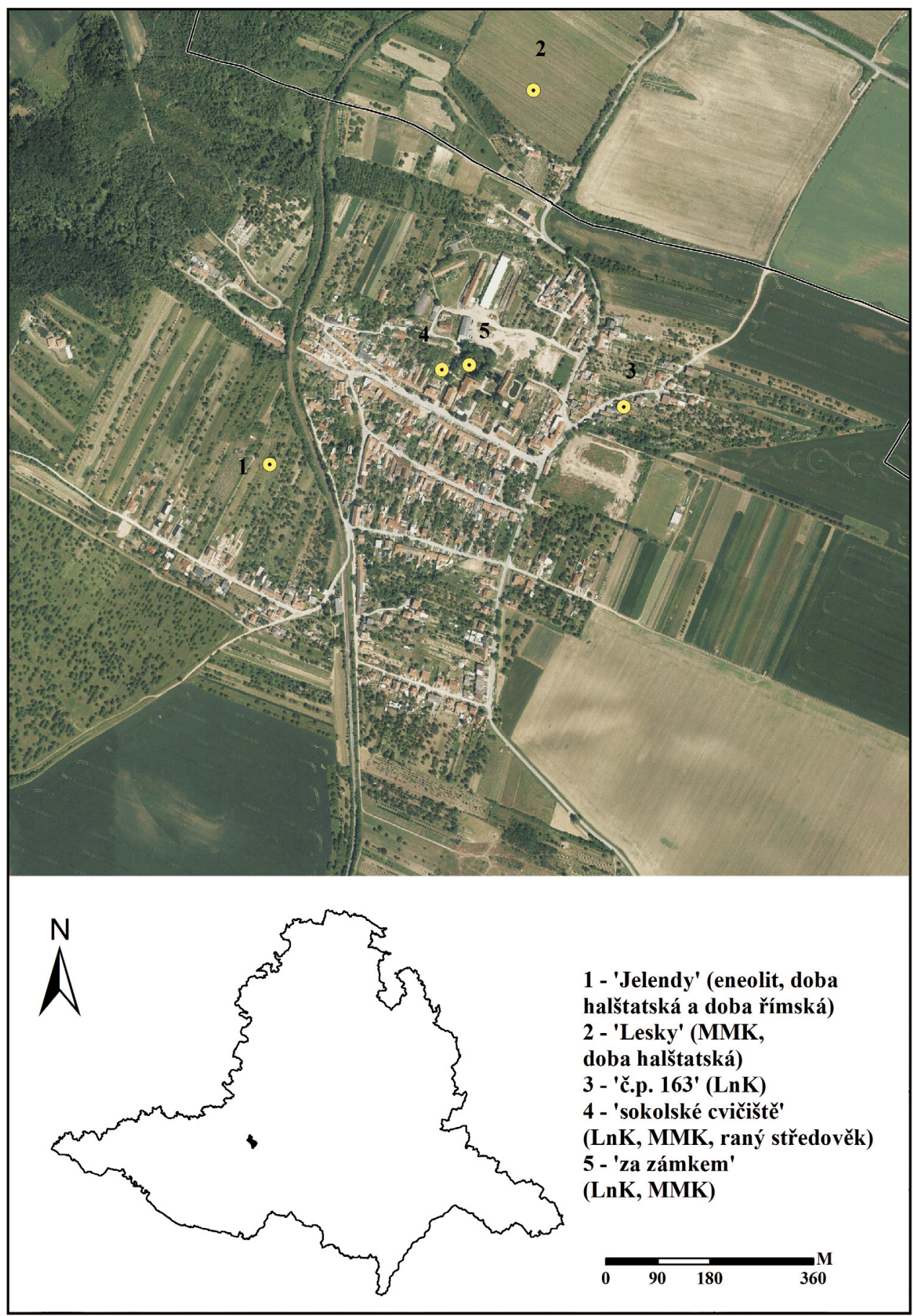

Obr. 1. Bohutice. Poloha zájmové oblasti a lokalizace dřívějšího osídlení (digitalizace H. Koubková).

Fig. 1. Bohutice. Localisation of the area of interest and of earlier settlement (digitisation by H. Koubková). 
kultury (Podborský - Vildomec 1972, 150), tuto informaci se však nepodařilo ověřit. Nejnověji byly doklady osídlení kultury s LnK zachyceny během záchranného výzkumu vyvolaného stavbou kanalizace v obci v roce 2015. Jednalo se o dva objekty obsahující charakteristickou keramiku, nacházely se před domem č. p. 163 (Čižmár 2016, 159), tedy asi 380 m východním směrem sídliště v prostoru sokolského cvičiště. Jedná se tedy o dvě rozdílné polohy.

Podle dalších zpráv bylo v roce 1932 nedaleko sokolského cvičiště (přesnější polohu neznáme; Skutil 1947) objeveno sídliště kultury s moravskou malovanou keramikou (dále jen MMK). Osídlování shodných nebo téměř shodných poloh kulturami s LnK a MMK patří k již známému fenoménu neolitu, který máme doložený i z mnoha dalších lokalit na Znojemsku, potažmo na celé Moravě (Kazdová 1997a, $b$; 2001; 2004). V poslední době bylo osídlení kultury s MMK objeveno také v poloze „Lesky“ na jihovýchodním úpatí odtěženého vrchu Leskouna. Průzkum byl proveden formou povrchových sběrů, a kromě fragmentů keramiky kultury s MMK byly objeveny také halštatské střepy (Kuča 2015, 145).

Osídlení na katastru Bohutic pokračovalo i počátkem eneolitu, z této doby máme doklad v podobě náhodného nálezu keramiky jordanovské kultury, bohužel bez dalších průvodních informací. Spolehlivější doklady máme až o přítomnosti nositelů kultury se zvoncovitými poháry, a to v podobě žárového hrobu, objeveného na pozemku F. Franty, a náhodných nálezů keramiky. Kromě toho evidujeme z období eneolitu ještě ojedinělý nález BI z trati "Jelendy“. Tato poloha, nacházející se na mírném, východně orientovaném svahu při jihozápadním okraji obce za železniční tratí, byla opakovaně osídlována také v době bronzové, halštatské i římské, kdy zde evidujeme nálezy keramiky a sídlištních objektů. Známá poloha sokolského cvičiště byla znovu osídlena v průběhu 10.-11. století, kdy zde existovalo slovanské sídliště a pohřebiště (Podborský - Vildomec 1972, 150).

Několik předmětů se nachází rovněž ve sbírkách Národního musea v Praze, jedná se o milodary z hrobu kultury se zvoncovitými poháry: dvě nádoby a dvě nátepní destičky.

Při revizi sbírek v Městském muzeu v Moravském Krumlově byl objeven jeden typický střep kultury s LnK (inv. č. 317) a navíc v inventární knize vedené Josefem Kaufmanem uvádí nálezy keramiky kultury s LnK a kostí (inv. č. 7457-7481) z polohy „zahrada Františka Franty“ nalezené při regulování kvưli vinohradu. Jedná se tedy o stejnou polohu, kde byl objeven také hrob kultury se zvoncovitými poháry.

\section{Materiál kultury s lineární keramikou ve sbírkách Moravského zemského muzea}

\subsection{Keramika}

Ve sbírkách Moravského zemského muzea je z katastru Bohutic zachováno celkem 18 kusů keramiky, což je, vzhledem $\mathrm{k}$ výše avizovaným zjištěním o pravěkém osídlení, velmi malé množství. Z tohoto počtu 16 kusů nese označení „sběr za zámkem 1965“, což označuje lokalizaci a pravděpodobně rok nálezu. Tato poloha se přitom nachází v těsné blízkosti sokolského cvičiště (obr. 1), nelze tedy vyloučit, že se jedná o pozůstatky téhož osídlení. Zbývající dva jedinci nenesou žádné bližší chronologické ani místní určení.

V rámci analýzy tohoto drobného keramického souboru byli vyčleněni tři jedinci, jenž je možné datovat do kultury s MMK. Jedná se o odlomený kulovitý výčnělek z plaveného keramického těsta, který zřejmě představoval plastickou výzdobu pohárku, dále pak výdut putny či hrnce z jemnozrnné hmoty a výdut z plaveného materiálu, která, na základě charakteristického 

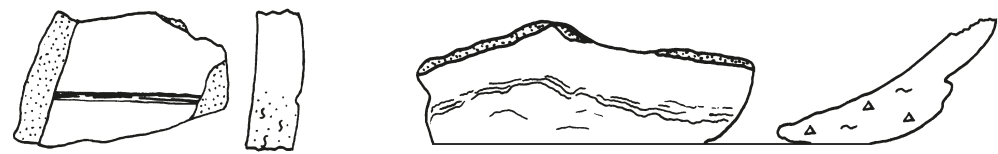

1

2
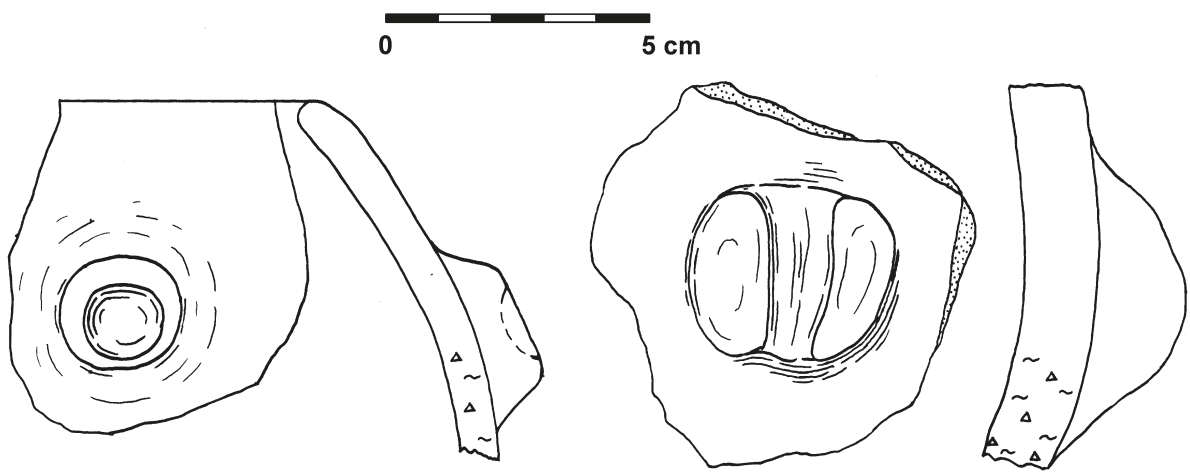

3
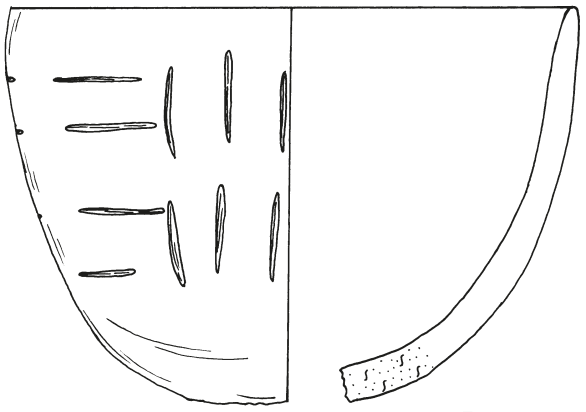

5

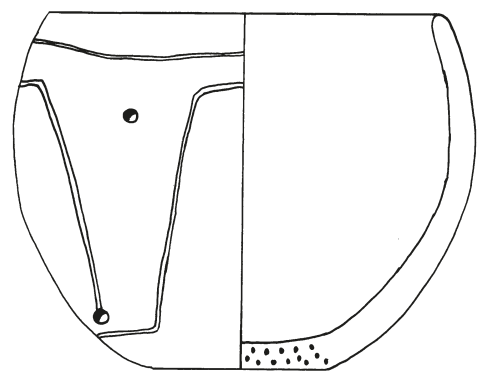

6

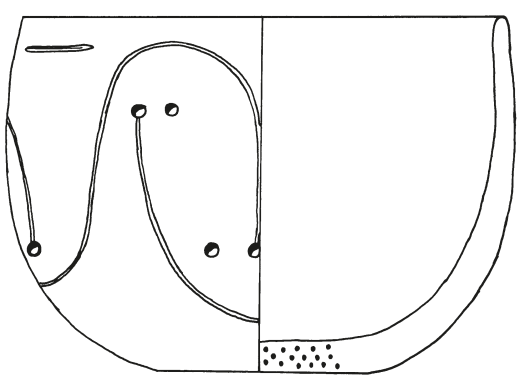

7

Obr. 2. Bohutice. Výběr keramiky kultury s lineární keramikou z polohy „za zámkem“ uložené ve sbírkách Moravského zemského muzea v Brně (kresba A. Čerevková).

Fig. 2. Bohutice. Selection of Linear Pottery from the location "za zámkem" stored in collections of the Moravian Museum in Brno (drawing by A. Čerevková). 
zalomení, pravděpodobně pochází z pohárku. Žádný z těchto nálezů není více chronologicky citlivý. Nález střepů kultury s MMK spolu s keramikou kultury $\mathrm{s}$ LnK $\mathrm{v}$ tomto případě pouze potvrzuje informace o shodném osídlování stejných poloh, což se v Bohuticích objevilo již v souvislosti s osídlením v areálu sokolského cvičiště. Kultuře s LnK lze tedy s jistotou přiřadit 15 jedinců.

Většinu dané kolekce tvoří výdutě neurčených typů nádob, objevilo také jedno dno (obr. 2: 2), okraj a část nádoby, dvě nádoby se podařilo rekonstruovat do původního tvaru. Jemná keramika mírně převažuje nad hrubou v počtu devíti kusů ku šesti. U jemné keramiky byla použita především tvrdá plavená hmota s organickou př́měsí a kaménky, u hrubé keramiky pak bahnitá tvrdá hmota, rovněž s organickou příměsí a kaménky. Charakter použitého keramického těsta je celkově spíše hrubý, povrch nádob byl mírně ohlazen, pouze u dvou jedinců byla pozorován dokonaleji ohlazený povrch. Hrubší keramické produkci odpovídá rovněž síla střepů, která se pohybuje v hodnotách kolem $10 \mathrm{~mm}$. Dané znaky jsou typické pro starší fázi kultury s LnK (Čižmář 1998, 109-112), čemuž ostatně odpovídá také charakter výzdoby. Tu neslo celkem šest jedinců, přičemž ve čtyřech případech se jedná o lineární ornament, ve dvou př́padech pak o plastický ornament. Plastická výzdoba byla zachována $\mathrm{v}$ podobě zátkovitého (obr. 2: 3) a vertikálně členěného (obr. 2: 4) výčnělku. Výzdobný motiv lineárního ornamentu se podařilo ve třech případech rekonstruovat. Dvakrát se objevil motiv ležatého „S“, a to jednou v kurvilineární (obr. 2: 7) a jednou v rektilineární (obr. 2: 6) variantě, přičemž linie byla vždy zakončena notou. Jedná se o oběžný motiv. V případě kurvilineární varianty byl hlavní motiv doplněn vedlejším motivem krátkých horizontálních rýžek umístěných mezi oblouky hlavní linie. Rektilineární varianta byla doplněna o prostou rytou linii pod okrajem ná- doby a volně umístěnými notami mezi oblouky hlavní linie. Třetí příklad lineární výzdoby představovaly krátké vertikální a horizontální rýžky uspořádané do sloupců a řad (viz obr. 2: 5). Poslední jedinec nesl výzdobu prostého rytého žlábku (obr. 2: 1). V souvislosti s tvarem nádoby se lineární výzdoba objevila na polokulovitých a globulárních nádobách. Užší vazbu na tvar nádoby však bohužel nelze prokázat.

Nepočetný soubor keramiky nemá ze statistického hlediska prakticky žádnou hodnotu, jeho význam spočívá zejména v chronologické pozici. Na základě charakteru keramické hmoty, a především výzdoby by dochované fragmenty odpovídaly fázi Ib, respektive přelomu fází Ib-IIa dle relativní chronologie. Pro tuto fázi je mimo jiné typická přítomnost volných kruhových not na pozadí hlavního motivu, mezi charakteristické prvky můžeme dále zařadit motiv krátkých horizontálních linií doplňujících hlavní motiv (Čižmár 1998, 109). Motiv ležatého „S“ (kurvilineární varianta) byl zjištěn např. v Těšeticích Kyjovicích (Vostrouská - Prokeš 2013, 114, 117), známe ho také z nedalekého pohřebiště ve Vedrovicích (Čižmář 2002, 172-174). Motiv krátkých horizontálních linií doplňujících hlavní motiv se objevil např. v Žádovicích (Čerevková 2015, 76). Považujeme jej za vliv z prostředí východních a jihovýchodních skupin LnK, kromě zmíněných Žádovic jej známe také z Mikulova - „Jelení louky“ či Bořitova - „Písku“ (Čižmář 1998, 109), nejnověji byl zjištěn také na keramickém materiálu z Blučiny - „Nivek“ (Hájek - Čerevková - Koubková 2017, 24).

\subsection{Kamenná industrie}

\section{Martin Kuča}

Soubor kamenné industrie z fondů Moravského zemského muzea je nepočetný a neexistuje k němu doprovodná dokumentace. Úvodem je třeba uvést i to, že některé artefakty mohou 

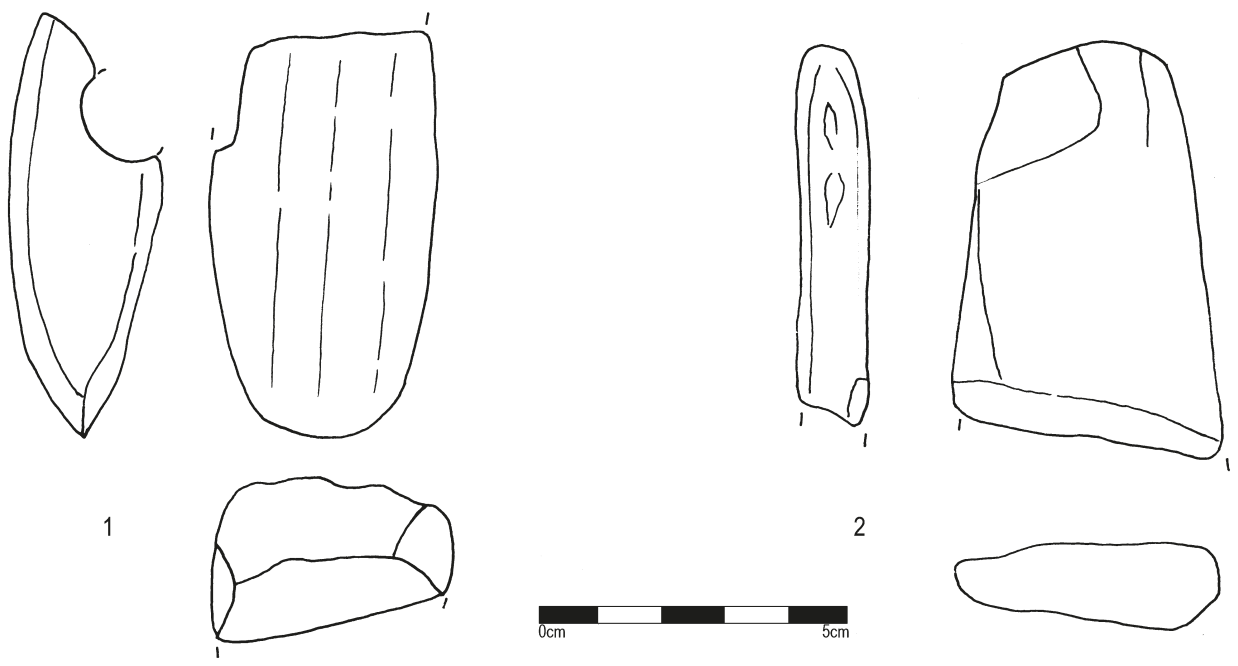

2

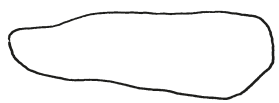

Obr. 3. Bohutice. Broušené artefakty uložené ve sbírkách Moravského zemského muzea v Brně (kresba $A$. Kuča).

Fig. 3. Bohutice. Polished stone artefacts stored in collections of the Moravian Museum in Brno (drawing by A. Kuča).

souviset s mladšími časovými komponenty, které byly na katastru obce doloženy. $\mathrm{K}$ dispozici bylo pouhých 10 kusů štípané a 2 kusy broušené kamenné industrie. Jeden broušený artefakt představuje zlomek sekeromlatu, jenž svým provedením náleží do eneolitu, pravděpodobně do kultury s nálevkovitými poháry ${ }^{1}$ (viz obr. 3: 1), a proto byl z rozboru vyloučen. Suroviny štípané i broušené industrie byly determinovány makroskopicky.

\section{3 Štípaná industrie}

Malou kolekci štípané kamenné industrie lze na základě odděleného uložení a číslování pomocně rozdělit do dvou skupin. Pod číslem $\mathrm{Pa}$ 419/48 je celkem šest kusů. Pět z nich je zhotoveno z rohovce typu Krumlovský les (variety I) a jeden je silně přepálený, takže se jeho původ nedá zjistit. Jedná se o pět nevýrazných úštěpů, největší z nich dosahuje délky $50 \mathrm{~mm}$. Jediné jádro z krumlovského rohovce je jednopodstavové úštěpové, přibližně diskovitého tvaru. Druhá skupinka (inv. č. 69658-69661) sestává ze čtyř kusů. Všechny jsou odbity z rohovce typu Krumlovský les a až na jeden blíže nespecifikovaný kus jsou z variety I. Ve třech případech se jedná o úštěpy a $v$ jednom případě o bazální část čepele. Jeden úštěp na boční straně nese stopy opotřebení.

\subsection{Broušená kamenná industrie}

Jediný vyčleněný kus broušené kamenné industrie představuje fragment ploché sekery, jehož ostří je uraženo (viz obr. 3: 2). Týl je zarovnaný a mírně šikmo seříznutý. Zachovaná délka činí $66 \mathrm{~mm}$, šírka $43 \mathrm{~mm}$ a tlouštka $13 \mathrm{~mm}$. Předmět byl změřen příručním kapametrem typu KT-6 a jeho hodnota činí $7,55 \times 10^{-3}$ SI jednotek. I podle charakteristického zabarvení lze artefakt určit jako sekeru ze zelené břidlice typu Želešice. 


\section{Závěr}

Analýza osídlení kultury s LnK v Bohuticích přinesla další informace o osídlení dané kultury ve východní části jihozápadní Moravy. Daná lokalita je známá již z dřívějších výzkumů a publikací (Podborský - Vildomec 1972). Materiál pochází z povrchového průzkumu provedeného v zázemí obce za zámkem, pravděpodobně $\mathrm{v}$ roce 1965 . Na základě analýzy keramiky bylo možné osídlení datovat dle relativní chronologie na přelom fází Ib-IIa, a to především na základě charakteristické lineární výzdoby a keramické hmoty.

Velmi malý soubor štípané kamenné industrie je bez výrazných typů a chronologicky jej nelze spolehlivě zařadit konkrétnímu období či kultuře. U spíše úštěpového charakteru a suroviny pouze $\mathrm{z}$ variety I krumlovského rohovce lze velmi opatrně uvažovat, že se jedná o artefakty ze starší (?) doby bronzové. Pohřebiště a sídliště únětické kultury se nacházelo v trati "Jelendy“ (Tihelka 1953, 288; Podborský - Vildomec 1972, $150)$, navíc Krumlovsko bylo v té době intenzivně osídleno (Salaš 2009, 22-24). Po surovinové stránce ve všech případech uplatnil rohovec typu Krumlovský les, což je vzhledem k velké blízkosti zdrojů předpokládané. Kamenná sekerka by snad podle své stavby a užité suroviny mohla být přiřazena ke kultuře $\mathrm{s}$ moravskou malovanou keramikou.
Materiál analyzovaný v této studii je bohužel nepočetný, přesto je důležitý z hlediska chronologického postavení lokality. Nálezy z dřivějších výzkumů a zpráv nejsou v současné době již spolehlivě dohledatelné a podrobnější informace o jejich podobě se nezachovaly. Zdejší osídlení tak nebylo možné blíže datovat v rámci jednotlivých fází vývoje kultury s LnK. To umožnil až rozbor keramiky v této studii. Podle výše uvedené datace byla lokalita relativně současná např́ s nedalekým osídlením ve Vedrovicích (naposledy Anlauf - Rožnovský 2017, 178). V nedávné době bylo osídlení z odpovídajících fází zjištěno také ve Vítonicích (Humpola 2013, 163). Většina blízkých lokalit s osídlením kultury s LnK (např. Kubšice, Kadov, Miroslav, Miroslavské Knínice) však blíže datována nebyla. V tomto směru tedy představuje analýza materiálu z Bohutic určitý přínos do dalšího bádání.

Co se týče kamenné industrie, ukázalo se, že ani štípané ani broušené artefakty s osídlením kultury s LnK nemusejí souviset. V případě štípané industrie však nelze tuto skutečnost zcela vyloučit.

Do budoucna by bylo vhodné vyvinout úsilí v získání dalších informací o osídlení kultury s LnK v bohutickém katastru, a to zejména verifikováním dosud získaných informací, které však jsou již poměrně starého data a narážejí na nedostatek spolehlivých zdrojů.

1) Za odborné posouzení patří poděkování Dr. hab. PhDr. Lubomíru Šebelovi z Archeologického ústavu AV ČR v Brně, v.v.i. 


\section{Literatura}

Anlauf, J. - Rožnouský, D. 2017: Vedrovice (okr. Znojmo). Přehled výzkumů 58-1, 178-179.

Bina, J. - Demek, J. 2012: Z nížin do hor. Geomorfologické jednotky České republiky. Praha.

Čerevková, A. 2015: Sídliště kultury s lineární keramikou v Žádovicích (okr. Hodonín). Rukopis magisterské diplomové práce uložený na ÚAM FF Masarykovy univerzity v Brně.

Čižmár̆. Z. 1998: Nástin relativní chronologie lineární keramiky na Moravě. Acta Musei Moraviae, Sci. soc. LXXXIII, 105-139.

Čižmár̆, Z. 2002: Keramika z pohřebiště v „Široké u lesa“. In: Podborský, V. et al.: Dvě pohřebiště neolitického lidu s lineární keramikou ve Vedrovicích na Moravě. 151-190, Brno.

Čižmár̆, I. 2016: Bohutice (okr. Znojmo). Přehled výzkumů 57-1, 159.

Demek, J. (ed.) 1987: Zeměpisný lexikon ČSR. Hory a nížiny. Praha.

Hájek, Z. - Čerevková, A. - Koubková, H. 2017: Osídlení lidem kultury s lineární keramikou v poloze „Nivky“ u Blučiny. Acta Musei Moraviae, Sci. soc. CII-1, 17-38.

Humpola, D. 2013: Vítonice (okr. Znojmo). Přehled výzkumů 54-1, 162-163.

Kazdová, E. 1997a: Poznámky k postlineárnímu neolitu na jihozápadní Moravě. In: Nekuda, R. - Unger, J. (eds.): Z pravěku do středověku, 36-41. Brno.

Kazdová, E. 1997b: Vztahy mezi lidem s vypíchanou a moravskou malovanou keramikou. Sborník pra- cí Filozofické fakulty brněnské univerzity, řada $\mathrm{M}$ 2, 79-88.

Kazdová, E. 2001: Osídlení střední Moravy v postlineárním neolitu. Pravěk Supplementum 8, 78-96.

Kazdová, E. 2004: Osídlení lidem s keramikou vypíchanou na Znojemsku. In: Kazdová, E. - Měřínský, Z. - Šabatová, K. (eds.): K poctě Vladimíru Podborskému. Přátelé a žáci k sedmdesátým narozeninám. Brno.

Kuča, M. 2015: Bohutice (okr. Znojmo). Přehled výzkumů 56-1, 145.

Oliva, M. 2010: Pravěké hornictví v Krumlovském lese. Vznik a vývoj industriálně-sakrální krajiny na jižní Moravě. Brno.

Podborský, V. - Vildomec, V. 1972: Pravěk Znojemska. Brno-Znojmo.

Salaš, M. 2009: Nejstarší obyvatelé přicházejí. Vývoj pravěkého osídlení Moravskokrumlovska. In: Moravský Krumlov ve svých osudech. Brno, 11-30.

Skutil, J. 1930: Moravské prehistorické výkopy a nálezy za rok 1929. Prríroda 23, 203-229.

Skutil, J. 1946: Moravské prehistorické výkopy a nálezy za rok 1932. Časopis Moravského muzea 33, 135-144.

Tihelka, K. 1953: Moravská únětická pohřebiště. Památky archeologické 44, 229-328.

Vostrouská, I. - Prokeš, L. 2013: Model chronologického vývoje sídliště kultury s lineární keramikou v Těšeticích-Kyjovicích „Sutnách“. Studia Archaeologica Brunensia 18-I, 93-135. 


\section{The Findings of Linear Pottery Culture from Old Collections of Moravian Museum from Bohutice}

The analysis of LBK settlement at Bohutice yielded further information on settlement activities of this archaeological culture in the eastern part of Southwest Moravia. The above-mentioned locality is already known from earlier excavations and publications (Podborský - Vildomec 1972). The material was collected on the ground surface in the neighbourhood of the municipality behind the chateau, probably in 1965. The analysis of pottery finds enabled to date the settlement according to relative chronology to the turn between phases Ib-IIa, which is mainly based on characteristic linear decoration and ceramic substance. The above-mentioned dating indicates that the locality was relatively contemporaneous with, for example, the nearby settlement in Vedrovice (recently Anlauf - Rožnouský 2017, 178). Settlement from the relevant phases was recently also detected in Vítonice (Humpola 2013, 163). However, most of the nearby sites with LBK settlement (e.g. Kubšice, Kadov, Miroslav, Miroslavské Knínice) were not dated in detail. The analysis of finds from Bohutice thus represents some benefit to future research.
A very small assemblage of chipped stone industry does not contain any distinctive types so that it cannot be reliably ascribed to the one or another period or archaeological culture. All of the artefacts found were made from the Krumlovský les chert, which is well understandable with regard to the short distance of the site from resources of this raw material. As regards lithic industry, it turned out that the chipped and polished artefacts are not necessarily associated with LBK settlement. This fact, however, cannot be completely denied in the case of chipped industry. Polished industry, on the other hand, most probably falls within the period of Moravian Painted Ware Culture and the Eneolithic Period.

In the future it would be suitable to make efforts to obtain further information on LBK settlement in cadastral district of Bohutice, mainly by verifying the presently known information which is already relatively old and insufficiently founded.

\section{Mgr. Zdeněk Hájek, Ph.D.}

- Archeologický ústav, Historické muzeum, Moravské zemské muzeum,

Zelný trh 6, 65937 Brno, Česká republika zhajek@mzm.cz

\section{PhDr. Alena Humpolová}

- Archeologický ústav, Historické muzeum, Moravské zemské muzeum, Zelný trh 6, 65937 Brno, Česká republika humpolova@mzm.cz

\section{Mgr. Alžběta Čerevková}

- Archeologický ústav, Historické muzeum, Moravské zemské muzeum, Zelný trh 6, 65937 Brno, Česká republika acervenkova@mzm.cz 